\title{
An Appraisal of Burnout among the University Lecturers in Ekiti State, Nigeria
}

\author{
Edith O. Olorunsola ${ }^{1}$ \\ ${ }^{1}$ Institute of Education, Ekiti State University, Ado Ekiti, Ekiti State, Nigeria \\ Correspondence: Edith O. Olorunsola, Institute of Education, Ekiti State University, Ado Ekiti, Ekiti State, \\ Nigeria. Tel: 234-803-684-7777. E-mail: funmiladebayo@yahoo.com
}

Received: June 6, 2012

doi:10.5539/jedp.v3n2p133

\author{
Accepted: April 11, $2013 \quad$ Online Published: October 14, 2013 \\ URL: http://dx.doi.org/10.5539/jedp.v3n2p133
}

\begin{abstract}
This survey investigated, identified and described the status of burnout among the university lecturers in Ekiti State University. A sample consisted of 80 respondents made up of 52 male and 28 female lecturers. One research question was raised and one hypothesis was generated and tested at 0.05 level of significance using t-test, mean and standard deviation. The result of the analysis showed that there was a high level of burnout among the lecturers. The study further revealed that there was a significant difference between burnout across the ages of lecturers. Based on the findings, it was recommended that the university management should create an atmosphere that promotes health through recreation in form suitable to the age range of the lecturers, study leave and a change of environment. Also, the university management should create job enrichment for employees that perform same work. Also recommended was that all the lecturers should be allowed to go on compulsory leave yearly to refresh themselves and get out of boredom.
\end{abstract}

Keywords: emotional exhaustion, burnout, work environment, university management

\section{Introduction}

What exactly is Burnout? It is defined in Merriam webster's collegiate dictionary as exhaustion or physical or emotional strength or motivation usually as a result of prolonged stress or frustration. Many are afraid of losing their jobs and not promoted therefore working harder and longer hours to prove their worth. These are those who work hard and do not receive the gratitude they feel they deserve from their bosses. They go to work every-day, work hard and do not feel they are rewarded properly. Maslach (2003), perceived burnout as a syndrome resulting from prolonged exposure to work stress that leads to withdrawal from organization. (Smith 1986) saw burnout as a psychological, emotional and sometimes physical withdrawal from a formerly enjoyable activity in response to excessive stress or dissatisfaction overtime.

\section{Literature Review}

Maslach and Leiter (1997) viewed burnout as a specific psychological condition in which people suffer emotional exhaustion, experience a lack of personal accomplishment and tend to depersonalize others.

Maslach and Jackson (1981) said burnout is a term that is used to describe a syndrome of emotional exhaustion and cynicism that occurs in response to the stressor and strains of professional life. Freudenberger (1974) expressed that burnout is a specific psychological condition in which people suffer emotional exhaustion, experience a lack of personal accomplishment and tend to depersonalize others.

Maslach (2003) added that burnout is job related and a prolonged response to chronic, emotional and interpersonal stressors on the job. Pines (1993) opined that Burnout system include but not limited to fatigue, poor self-esteem, inability to concentrate on a subject and a tendency to blame others. Maslach, Jackson and Leiter (1996) in their opinion believed that individual suffering from burnout, experience a depletion of physical and emotional resources, develop cynical attitudes and feel a loss of professional self-efficiency. Dunham and Varma (1998) noticed that most persuasive symptoms of teacher burnout are a noticeable lowering level of job commitment, a loss of enthusiasm and interest, a feeling of dissatisfaction and alienation. They further added that in addition to negative effects of burnout on individuals, organizations also face significant implications and cost associated with burnout. Tracy (2000) asserted that burnout is personal and private and problematic when its function is to disregard the way burnout is, largely an organisation issue caused by long hours, little down time, 
continual peer, customer and superior surveillance. Maslach and Englewood (1982) reiterated that employees exposed to such things as unresolved interpersonal conflicts, lack of clearly defined tasks and responsibilities, extreme over work, lack of appropriate rewards or presence of inappropriate punishment may become victims of burnout. These processes make workers become less committed to their jobs and begin to withdraw from work. The process of withdrawal may include such reaction as increased tardiness and absenteeism and decreased work performance. Halbesleben and Buckley (2004) observed that among these negative impacts, organizations experience lower individual work performance, high rate of turnover, lower levels of organizational commitment, low reported job satisfaction, high health care cost and decreases creativity, problem solving and innovation.

Observation has shown that burnout is a growing problem in business, institutions and organisations. Many lecturers are worn-out, complaining of fatigue, anxiety and workload. Researches have revealed that at some point in one's career burnout will be experienced, regardless of how much a person loves his job, there will be a time when a person will not feel like doing it anymore. Observation further shows that the successes or failure of any institution is to a great extent dependent on the group that make up such institution. The national policy on education (2004) asserted that no education system can rise above the quality of his teachers. Effective utilization of the intellectual ability of the lecturers helps in the development of the universities and the society at large. Work environment of any society has a magnetic capability of influencing staff behaviour positively or negatively depending on whether the organizational climate is friendly or hostile. If the work environment is harsh and drab, not meeting the needs of the lecturers, it could cause burnout. Ajala (1991) says the way a worker perceives his environment, influence the way the person actually behaves in the environment. Non-conducive environment, strike actions un-fulfilment at work may result in suspended activities and in a situation where the university management trivializes the welfare of the workers and high priority is not accorded their promotion, advancement, remuneration, health and recreation. Hence, if the university gives room for conflict between them and the lecturers, it could result in burnout. The conflict between the students and the university management has made the university calendar so unstable, irregular and unrealizable. This has resulted in the work accumulation for the lecturers and having annual leave when they can travel with their families and relax from work stress has become impossible.

Burnout as presented seems to be a significant issue among the university lecturers and it appears to be a cankerworm that is eating deep into the health of the lecturers. It requires an immediate attention from the university administrators to arrest this situation, so that effective productivity will be enhanced and the educational goals could be achieved and attained. An overview of the situation in Ekiti state university revealed that the work for the lecturers is much, coupled with a lot of pressure from the students and the community. Lecturers have to write academic papers before they can be promoted, despite the fact that the environmental conditions are sometimes contrary to academic pursuit and the resources are grossly inadequate. In Nigeria, economy has been bastardised by the leaders and this has encouraged epileptic supply of electricity in the university, making it difficult for lecturers to do research and write academic papers. With the growing population of university students the lecturers have so much to do within a limited time, ranging from teaching the regular and the distance learning students, supervision of examinations, marking, recording and computation of students results, being course advisers to students and doing other administrative work in the school. These heavy responsibilities combined with limited resources, long hours, hostile working condition and sometimes unimaginable demands from students and the community leads to chronic stress and ultimately burnout. Realistically speaking, one would expect female lecturers to experience burnout more than their male counterparts because of the pressure of dual role they have to face. That is, the domestic chores at home and the academic work. Many of the female lecturers often complain of symptoms of burnout and the effect could be seen as many getting sick, having grey hair and ageing than their counterparts in other sectors. Burnout appears to be a growing problem in many professions but it is mostly common in helping professions; but less attention seems to be paid to this particular concept. Lecturer as well as administrators, counsellors, doctors, nurses, police officers have the additional burden of extreme responsibility for the well being of others. Burnout has revealed more attention than overstraining or staleness in anecdotal reports as well as research investigations. Observation has shown that Ekiti state university's lecturers seems to be cumbered with much work and in an unfavourable condition which seem to dampen their morale and de-motivate them for effective job productivity or performance. Lee and Ashforth (1993) identified three phases of burnout as emotional exhaustion caused by excessive demands placed on lecturers while the second stage is depersonalization or developing of a cynical, insensitive attitude towards people or other workers. The third stage is marked by feeling of low accomplishment. Here, the workers experiencing burnout feel a sense of frustration and helplessness. Workers begin to feel that the energy expended on their work could not produce the expected results and they may give up trying. Observation has shown that these phases of burnout may cause lecturers insensitivity towards students, lower 
tolerance level with students, feeling that they are no longer able to help students learn. Emotional exhaustion can occur when lecturers' resources are depleted and they think that they are psychologically exhausted. Maslach and Leiter (1982) identified six major influences as workload, lack of control, over establishing and following day to day priorities, insufficient reward and accompanying feelings of community in which relationship become impersonal and team work is undermined, the absence of fairness in which trust, openness and respect are not present and conflicting values in which choices that are made by management often conflict with their mission and care values. Obviously, the presence of each of these could certainly indicate a strong likelihood of the development of burnout symptoms in an individual. It is noteworthy that any single one of these could also lead to display symptoms of burnout. Given these state of affairs therefore, this study seeks to appraise and describe the status of burnout among the university lecturers in Ekiti State University.

\subsection{Purpose of the Study}

The purpose of the study is to ap praise and describe the status of burnout among the University Lecturers in Ekiti State and to find out the effect on male and female lecturers.

\subsection{Research Questions}

(i) What is the status of burnout among the University Lecturers?

(ii) Is there any significant difference between burnout of male and female lecturers?

\subsection{Null Hypothesis}

There is no significant difference between the burnout of male and female lectures in the University.

\section{Method}

A descriptive research design of the survey type was used for the study. The population for the study was 80 respondents from the lecturers in Ekiti State University. Multi-stage sampling technique was used in selecting the sample for the study.

\subsection{Research Instrument}

A self-constructed questionnaire titled burnout questionnaire (BOQ) was used for the data collection. Face and content validity of the instrument was ascertained by experts. The validity of the instrument was 0.325 , while the reliability of the instrument was also established with reliability co-efficient of 0.820 .

\section{Data Analysis and Result}

What is the status of burnout among the lecturers?

Table one show the burnout status among the lecturers

Table 1. Burnout status among lecturers

\begin{tabular}{llll}
\hline Variables & $\mathrm{N}$ & Mean & S.D \\
\hline Burnout & 80 & 70.20 & 18.42 \\
\hline
\end{tabular}

The table shows the mean score and the standard deviation of the level of burnout of academic staff in the university. The mean score was 70.20 while the standard deviation was 18.42 . This shows that there was a high level burnout among the lecturers in the University.

Table 2. Test for gender and burnout of sex of male and female lecturers

\begin{tabular}{lllllll}
\hline Sex & N & Mean & S.D & DF & t-cal & t-table \\
\hline Male & 63 & 71.79 & 19.23 & 78 & 1.39 & 1.51 \\
Female & 10 & 64.63 & 14.41 & & & \\
\hline
\end{tabular}


Table 2 shows the mean score for male lecturers as 71.79 and for female as 1.39 while the corresponding t-table was 1.51 since the $t$-table was greater than the $t$-calculated, the null hypothesis was accepted. Hence there is no significant difference between the burnout of male and female lecturers in the University.

\section{Discussion}

The data revealed that lecturers in Ekiti state University have a high level of burnout the mean was 70.20 and the standard deviation was 18.42. The high level status of burnout of lecturers might be as a result of the work environment of the lecturers. The work environment was perceived by the sample as not conducive and drab. The lecturer's offices are choky, unequipped with necessary facilities that could stimulate them to work effectively or keep longer hours at work to do a meaningful research work. Furthermore, the libraries are considered shadows of what they ought to be. Irregular supply of electricity makes accessibility to the internet difficult making writing and preparing for academic papers cumbersome. Notably too, they considered classrooms not well equipped for proper teaching to take place coupled with overcrowded population of students. This scares the lecturers and makes thorough teaching a herculean task while easy communication to such a crowd makes interaction difficult and ineffective. Fox (1974) opined that it is good climate that makes an institution a good place to be a satisfying and meaningful situation in which people spend substantial portion of their time.

Olorunsola (2010) asserted that an enriched environment with adequate facilities seem to have a magnetic effect of raising the morale and tempo of lecturers but absence of such necessary facilities impede the hardworking lectures and even cause dissatisfaction and ineffectiveness job performance. She further said if the university environment is hostile to the values and skills of lecturers, then negative reactions like turnover, absenteeism, lateness, strike and unnecessary agitations from academic staff union of the universities, reduced effort and increased rate error and neglect of duty may prevail. Charles and Jeff (2007) in their analysis said some favourable working conditions for employees such as clean working conditions which include working in an environment where there is little possibility of being injured, having little noise in the work area, working in an environment where there is little possibility of physically hurting workers, having a specious convenient work environment, having sufficient lightning in the work area, well ventilated with rest rooms conveniently placed in the work area all these could boost the morale of workers to satisfaction and prevent brain drain and burnout.

In the last few decades, lecturers in higher institutions in Nigeria hardly go on annual leave or vacations because of the incessant strike orchestrated by government insensitivity to welfare and academic needs of lecturers in the universities. This has made the university calendar unrealisable and therefore lecturers have had to cover lost grounds at the expense of their annual leave and vacations. All these seem to have resulted in burnout for the lecturers.

Table 2 revealed that there is no significant difference between male and female lecturers burnout. The $\mathrm{t}$-calculated was 1.39 which is less than 1.40 on the corresponding t-table. In the real sense of it, one would expect that there would be a significant difference in the burnout of female because of the dual role played by female lecturers as they have a lot of domestic work competing with their secular job which might affect their psyche, performance and output. Viewing the non-significant difference, this could be as results of the same condition both male and female lecturers were exposed to and the same training they had during their undergraduate days.

The non-significance of these male and female lecturers could be due to the same intellectual ability and capability possessed in performing any given task.

\section{Conclusion}

The study appraised the status of burnout among University lecturers in Ekiti State. The study revealed that there was a high status of burnout among the University lecturers in Ekiti State. Similarly, there was no significant difference in the burnout status of male and female lecturers in the University.

\subsection{Recommendations}

Since burnout contribute in no small measure to ill-health of lecturers, the University management should pay more attention to lecturers health by providing free health services to them. The lecturers should be provided with a well equipped sickbay where lecturers can know the condition of their health from time to time. Also, a good recreational environment should be provided for relaxation. Lecturers should be allowed to go for their annual leave to get out of boredom. Conferences, seminars and workshops should be organized for these lecturers, where they can interact with other people in their field both in Nigeria and abroad so as to relieve them 
of boredom, stress and burnout. Lecturers should schedule their work in a way that will not affect their health adversely, take time to rest after work and always check their state of health.

\section{References}

Ajala, A. T. A. (1991). A study of factors affecting academic performance of students in selected federal and state secondary schools in Lagos State. Unpublished M. Ed. Thesis, University of Lagos.

Charles, G. A., \& Jeff, A. (2007). Analysis of Management and Employee Job Satisfaction. The International Journal of Applied Management and Technology, 2(2), 97-115.

Dunham, J., \& Varma, V. (1998). Stress in teachers: Past, Present and Future (pp. 120-138). London: Whur Publishers Ltd.

Fox, R. S. (1974). School Climate Environment. Phi Delta Kappa.

Freudenberger, H. J. (1974). Staff Burnout. Journal of Social Issues, 30(1), 159-165. http://dx.doi.org/10.1111/j.1540-4560.1974.tb00706.x

Halbesleben, J. R. B., \& Buckley, M. R. (2004). Burnout in Organizational Life. Journal of Management, 30(6), 859-879. http://dx.doi.org/10.1016/j.jm.2004.06.004

Lee, R. T., \& Ashforth, B. E. (1993). A Longitudinal Study of Burnout among Supervisors and Managers: Comparisons between the Leiter and Maslach (1988) and Golembiewski et al. (1986) Models. Organizational Behavior and Human Decision Processes, 54(3), 369-398. http://dx.doi.org/10.1006/obhd.1993.1016

Maslach, C. (1982). The Burnout: The Cost of Caring. Engelwood Cliffs: Prentice Hall.

Maslach, C. (2003). Job Burnout: New Direction in Research and intervention Current Direction in Psychological Science, 12, 189-192. http://dx.doi.org/10.1111/1467-8721.01258

Maslach, C., \& Jackcon, S. E. (1981). The measurement of experienced burnout. Journal of occupational Behaviour, 12(2), 99-113. http://dx.doi.org/10.1002/job.4030020205

Maslach, C., Jackson, S. E., \& Leiter, M. P. (1996). The Maslach Burnout Inventory: Manual. Palo Alto: Consulting Psychologist Press.

Maslach. C., \& Leiter, M. P. (1997). The truth about Burnout. San Francisco, CA, Jossey-Bass.

Olorunsola, E. O. (2010). Job Satisfaction and performance of Administrative staff in South West Nigeria Universities. (Unpublished)

Pines, A. (1993). Burnout: An existential Perspective. In W. B. Schaufeli, D. Maslach, \& T. Marek (Eds), Professional Burnout Research Development in Theory and Research. Washington D. C. Taylor and Francis.

Smith, R. E. (1986). Towards a cognitive-affective model of athletic burnout. Journal of sports of Psychology, 8 , $36-50$.

Tracy, S. J. (2000). Becoming a character for commerce: Emotion labor, self-subordination, and discursive construction of identity in a total institution. Management Communication Quarterly, 14, 90-128. http://dx.doi.org/10.1177/0893318900141004

\section{Copyrights}

Copyright for this article is retained by the author(s), with first publication rights granted to the journal.

This is an open-access article distributed under the terms and conditions of the Creative Commons Attribution license (http://creativecommons.org/licenses/by/3.0/). 